\title{
Contraceptive options for women with SLE
}

May I congratulate the authors of the commentary describing contraceptive options for women with systemic lupus erythematosis (SLE). ${ }^{1}$ This was a comprehensive summary and I was interested in their views regarding the suitability of progestogen-only methods in women with antiphospholipid antibodies. The authors felt these methods were unsafe in such women (World Health Organization Medical Eligibility Criteria for Contraceptive Use Category 3 - generally risks outweigh the benefits of use). As up to $42 \%$ of women with SLE will be positive for these antibodies ${ }^{2}$ the authors are reducing contraceptive choice to barrier methods, copper intrauterine devices or sterilisation.

About one-third of women with antiphospholipid antibodies develop a venous thromboembolism (VTE) in their lifetime and this risk is further increased in pregnancy and the puerperium. ${ }^{2}$ Maternal mortality in women suffering from SLE is thought to be $2-3 \% .^{3}$ We now have good evidence that progestogen-only contraceptive methods such as the levonorgestrel-releasing intrauterine system and desogestrel pill do not increase the risk of VTE in the general population. ${ }^{4}$ A recent study also suggested that oral pregnane progestogen contraceptives appear to have little effect on the development of VTE in women with SLE (where $29.4 \%$ of 187 women had detectable antiphospholipid antibodies). ${ }^{5}$

Perhaps the authors would like to provide an additional comment?

Diana Mansour, FRCOG, FFSRH

Consultant in Community Gynaecology and Reproductive Healthcare, Newcastle Hospitals, Community Health, New Croft Centre, Newcastle upon Tyne, UK:

Diana.Mansour@newcastle-pct.nhs.uk

Competing interests The author has received financial support to attend pharmaceutical advisory board meetings, undertake research studies, speak at educational meetings and conferences along with travel grants from Astellas, Bayer, Consilient Healthcare, HRA Pharma, Merck, Pfizer and Vifor Pharma. 


\section{REFERENCES}

1 Culwell KR, Curtis KM. Contraception for women with systemic lupus erythematosus. J Fam Plann Reprod Health Care 2012;26 October 2012 [Epub ahead of print].

2 Al-Homood IA. Thrombosis in systemic lupus erythematosus: a review article. ISRN

Rheumatol 2012;2012:Article ID 428269, 6 pages.doi:10.5402/2012/428269 [accessed 12 November 2012].

3 Iozza I, Cianci S, Di Natale A, et al. Update on systemic lupus erythematosus pregnancy. J Prenat Med 2010;4:67-73.

4 Lidegaard Ø, Løkkegaard E, Svendsen AL, et al. Hormonal contraception and risk of venous thromboembolism: national follow-up study. BMJ 2009;339:b2890.

5 Chabbert-Buffet N, Amoura Z, Scarabin PY, et al. Pregnane progestin contraception in systemic lupus erythematosus: a longitudinal study of 187 patients. Contraception 2011;83:229-237. 